\title{
Hydrological indications of aeolian salts in mid-latitude deserts of northwestern China
}

\author{
BING-Qi ZHU* \\ Key Laboratory of Water Cycle and Related Land Surface Processes, Institute of Geographic Sciences and \\ Natural Resources Research, Chinese Academy of Sciences, Beijing 100101, China. \\ ${ }^{*}$ Corresponding author. e-mail: zhubingqi@igsnrr.ac.cn
}

Large sandy deserts in middle latitude of northwestern China were studied on salt variations in modern and ancient aeolian sediments, aiming to explore their hydrological indications at the present and past. Globally, sulphate is rich in arid to semi-arid deserts, including the aeolian loess sediments in China and soils in low-latitude deserts, but is less common in the aeolian sediments from the mid-latitude deserts in this study. The compositional differences between aeolian salts and local natural waters is evident, indicating the chemistry of aeolian salts and the associated parent brines may be significantly different than that predicted for hydrologically closed systems. The formation of aeolian salts in the studied deserts is strongly controlled by earth surface processes in a large scale but not in a local scale. Vertical changes in facies and salinities are abrupt in the studied palaeo-aeolian sediment samples, which were interbedded by lacustrine/fluvial sediments with OSL and ${ }^{14} \mathrm{C}$ ages ranging between 40 and 2 ka BP, reflecting rapid high-amplitude changes in hydrological settings during late Pleistocene to later Holocene in these ancient playa systems. A great difference in salt composition between aeolian and lacustrine sediments suggests that the inorganic salt is a latent geoproxy in revealing local hydrological variations and climate change in the desert areas. But the environmental indications could be amphibolous for the sedimentary sequences with dual/multiple depositional end-members; under this situation an increase in sequence salinity does not always represent an enhanced environmental aridity. Ancient playas are arid or humid at the same time based on several sporadic records is not a valid approach to correlation of salt deposits in adjacent saline playa basin in the studied areas. Effects of earth surface processes including erosion, deposition and other processes on sediment properties will bias the hydrological implications of sediment salinity.

\section{Introduction}

Salt-bearing deposits in the world are commonly developed in the past or present arid basins (Warren 2006). These depositional settings reflect both climatic and tectonic conditions (Smoot and Lowenstein 1991; Warren 2006). Although formation of salts in many types of deposits (e.g., soils, playa and lake sediments) is supposed to be mainly controlled by climate factors, such as annual precipitation inputs, soil moisture changes, evapotranspiration losses, and solar radiation (Borchert and Muir 1964; Sinha and Raymahashay 2004; Warren 2006; Singer 2007; Singh et al. 2013), hydrological settings governed by local, regional and continental geological and morphological conditions are also important; because they determine the development of water systems, by which all solutes are introduced (Borchert and Muir 1964; Singer 2007).

Keywords. Aeolian salt; sequence salinity; hydrological indications; environmental geoproxy; earth surface processes; middle-latitude desert. 
Hydrological settings for salt deposits may be marine (thalassic), nonmarine (athalassic) or hybrid (Warren 2006). For marine salt deposits, due to consistent ionic proportions in seawater worldwide, modern marine salt deposits are predictable and tied to increasing salinity (Warren 2006). However, for nonmarine salt deposits, proportions vary according to source terrain and levels of hydrothermal input (Smoot and Lowenstein 1991). Hence, the compositions and sequence of salt precipitation in continental areas is more variable. For example, salt deposits can form from lake precipitates and efflorescences in cold polar deserts in Antarctica (Warren 2006), but the volumes of salt in these cryogenic regions are insignificant compared to arid settings closer to the equator (Singer 2007). Brine freezing and mixing processes, rather than direct solar concentration, plays a much more important role in the formation of most cold climate salts (Carlson et al. 1990; Marion et al. 1999, 2008). Besides, although modern nonmarine salts may typically accumulate within groundwater discharge regions in semi-arid to hyper-arid deserts (Borchert and Muir 1964, Smoot and Lowenstein 1991, Warren 2006), salt deposits in deserts at the continental scale are the result of large-scale atmospheric circulation (Zhu and Yang 2010; Zhu 2016). This means that both the regional climate and hydrology are critical to understanding the salt composition and distribution in desert areas.

Modern deserts cover more than $30 \%$ of the world's land surface, mostly within two belts lying $15^{\circ}-35^{\circ}$ north and south of the equator, known as the Horse latitudes. Atmospheric circulation at these latitudes could have a marked effect on hydrology in Quaternary deserts, because almost all modern continental playas in the Horse latitudes have experienced numerous water-full versus dry stages in the last few hundred thousand years (Magee 1991; Ullman and Collerson 1994; Ullman 1995; Li et al. 1996, 1997; Magee and Miller 1998; Magee et al. 2004; Yang et al. 2010, 2011). However, beyond the Horse latitudes, local topography induces variation in hydrology and climate that can drive desert/playa formation. For example, the playas and mid-latitude deserts of central Asia and central Australia are in part of product of their isolation from the nearest ocean, namely the continentality (Zhu and Yang 2010). It can explain why the highly continental Taklamakan Desert of northwestern China is a hyper-arid desert at $45^{\circ} \mathrm{N}$ latitude, well north of the Horse latitudes. Therefore, hydrological changes in the Quaternary deserts are critical to understand their formation and evolution.

Soluble salts in sedimentary sequences have been widely used as one of the environmental indicators to reconstruct palaeohydrological history from different geological records, such as oceans (Hay et al. 2006), lakes (Magee 1991; Ullman and Collerson 1994; Ullman 1995; Li et al. 1996, 1997; Magee and Miller 1998; Magee et al. 2004; Sinha and Raymahashay 2004; Liu et al. 2008), sandy deserts (Sun et al. 2008) and loess-paleosol sediments (Sun et al. 2006). In these studies, salt variations in sedimentary sequences are used to reflect past salinity conditions and hydrological changes in many parts of the world (Wasson et al. 1984; Last 1990; Dean and Schwalb 2000; Schutt 2000; Last and Vance 2002; Sinha and Raymahashay 2004).

However, due to the diverse sources and depositional dynamics, the hydrological implications of inorganic salt deposits in the desert environment remain unclear. Until now, few investigations have been involved into the hydrological indications of salt deposits in the middle-latitude deserts of northern China (Zhu and Yang 2010), even though they make up the majority of the temperate deserts in the Northern Hemisphere (NH).

In this work, a geochemical study about soluble inorganic salts in aeolian sediments from large deserts in northwestern China was carried out. The objectives are to explore the possible hydrological indications of soluble salts in aeolian sediments.

\section{Methodology}

The study areas and sampling sites were chosen from large sand seas in northwestern China (figure 1a), i.e., the Taklamakan Desert (the westerly climate control) and the Badanjilin Desert (the monsoon climate control). Both the modern and ancient aeolian sediments were designed to be sampled in the field. For modern aeolian sediment, 33 dunes in the Taklamakan Desert and 14 dunes in the Badanjilin Desert were sampled. The modern samples were mainly collected from the surface of active dunes, geographically located in the center and southern edge of the Taklamakan (figure 1b), and from the southern part of the Badanjilin (figure 1c-d).

In the inner part of the Taklamakan and the Badanjilin deserts, aeolian and lacustrine (or fluvial in Taklamakan) deposits (palaeo-sediments) are frequently found interbedded (Supplementary figure S1). For instance, lacustrine/fluvial layers in the center of the Taklamakan are easily observed along the recently built trans-desert highway (Supplementary figure S1a-b). Four sedimentary sequences with well exposed depositional layers were selected from hinterland areas of these deserts (figure 1). The Arerjilin-I profile is about $4 \mathrm{~min}$ depth in the Badanjilin Desert (figure 1d), with lacustrine sediments interbedded by aeolian sand layers (Supplementary figure S2a). The TazhongXIII profile is a lacustrine sequence, interbedded 

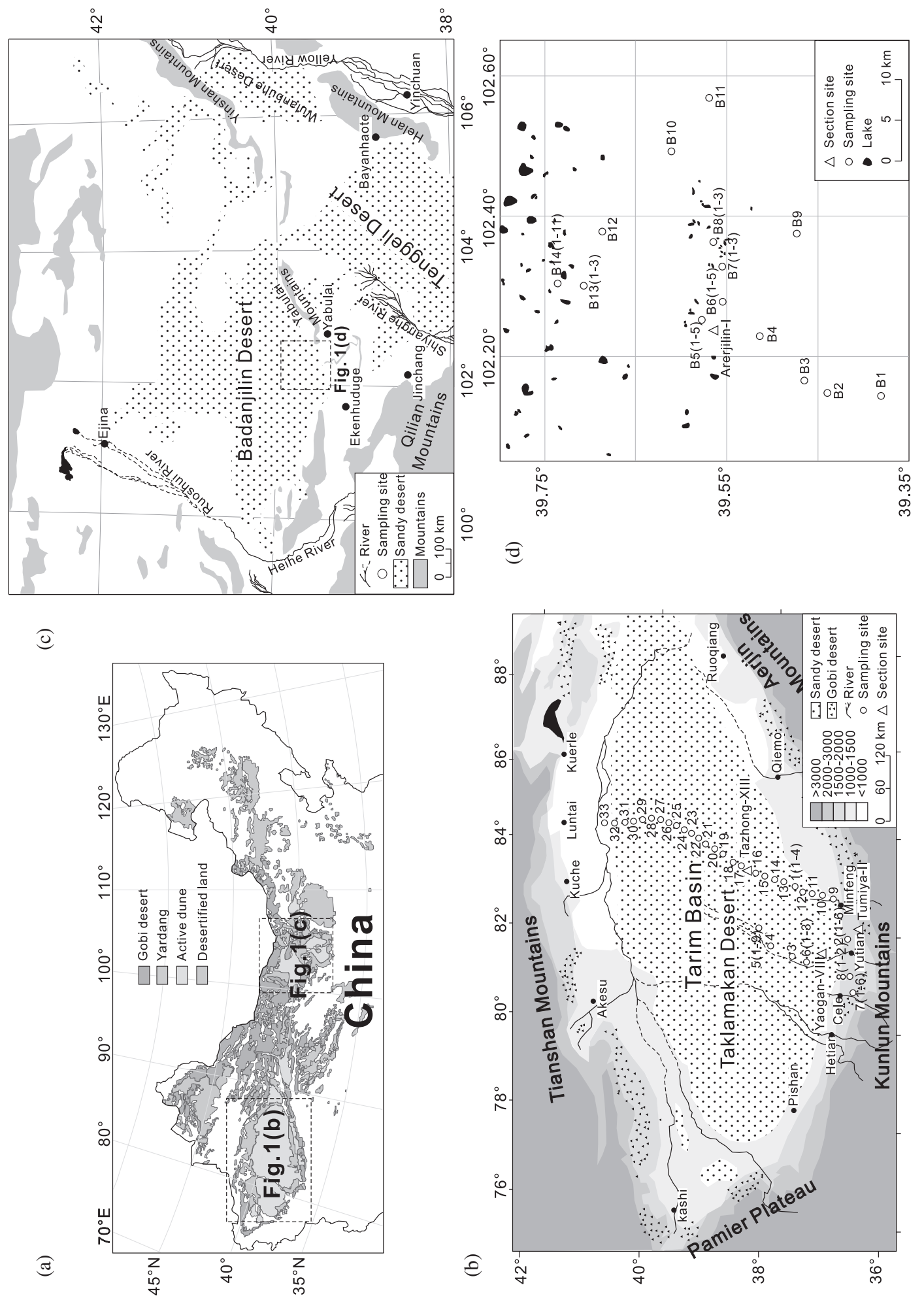
with aeolian sands in the Taklamakan Desert (Supplementary figure S2b). The Yaogan-VIII profile is close to the south margin of the Taklamakan Desert and is located at the lower reaches of the Keriya River (figure 1b), with its top buried by a 30-m active dune (Supplementary figure S2c). The Tumiya-II profile is close to the south edge of the Taklamakan Desert and is located at the low reaches of the Tumiya palaeochannel (figure 1b), with silty sand or sandy silt interbedded with several calcium-carbonate-cemented layers (Supplementary figure S2d). The lithology of lacustrine sediments differs greatly from the aeolian sands in all sections from these deserts. These sequences were chronologically analyzed based on optically stimulated luminescence (OSL) dating and radiocarbon $\left({ }^{14} \mathrm{C}\right)$ dating methods.

The analytical methods for soluble salt contents of aeolian sediment samples can be recorded from Zhu and Yang (2010), and the OSL and radiocarbon dating methods can be recorded from (Yang et al. 2006, 2010). The physical and chemical analytical data of the soluble salt compositions of sediments are shown in Supplementary tables S1 and S2, respectively. The result of OSL and radiocarbon dating ages are summarized in Supplementary tables S3 and S4, respectively. It should be noted that the partial characteristics of aeolian salts from the Taklamakan and Badanjilin Deserts were previously reported in the early works (Zhu and Yang 2010; Zhu et al. 2012) with preliminary descriptions of their composition and distribution and related influencing factors, but their potential hydrological indications are discussed here along with the stratigraphies and chronologic results.

\section{Results}

The calculated salinity values are $0.05-0.42 \%$ (mean $0.15 \%$ ) in the dune sediments of the Badanjilin Desert, with $\mathrm{pH}$ values ranging from 8.82 to 9.42 (mean 9.12). For the dune sediments from the Taklamakan Desert, the $\mathrm{pH}$ and salinity values range between 8.66 and 9.54 (mean 9.22) and $0.27 \%$ and $1.86 \%$ (mean $0.78 \%$ ), respectively. The range of $\mathrm{pH}$ values between the aeolian sediments is narrow (8.6-9.5), suggesting similar alkaline soil conditions and buffer capacities. Because $\mathrm{pH}$ values in soil between 6.4 and 12.2 are mainly caused by bicarbonate (6.4-10.3) and carbonate (10.3-12.2) (Wetzel and Likens 2000), consequently, the alkalinities of these aeolian salts are mainly determined by the carbon-bearing salts, particularly bicarbonate.

The salinities and $\mathrm{pH}$ values of the 15 palaeoaeolian sediment samples, with OSL ages ranging between 40 and 2 ka BP (Supplementary table S4), which are buried beneath modern dunes in the Taklamakan Desert, tend to be slightly higher in salinity and lower in $\mathrm{pH}$ than those of modern dune sand samples (figure 2a). The dune surface sediments, collected from the same months of different climatic year (autumns in an arid 2006 and in a wet 2008) in the Badanjilin Desert, are quite similar to each other (figure $2 b$ ).

The major anions of aeolian salts are $\mathrm{Cl}^{-}$and $\mathrm{HCO}_{3}{ }^{-}$and, the $\mathrm{SO}_{4}{ }^{2-}$ concentrations are relatively low in all samples (figure $2 \mathrm{~d}$ ). The first major cation is $\mathrm{Na}^{+}$, followed by $\mathrm{Ca}^{2+}$, while the concentrations of $\mathrm{K}^{+}$and $\mathrm{Mg}^{2+}$ are low (figure $2 \mathrm{e}-\mathrm{f}$ ). The concentrations of the carbon-bearing ions in dunesurface sediments are positively correlated with the $\mathrm{pH}$ values (figure 2c). According to the major ion concentrations, the mineralogy of aeolian salts can be classified as follows: $\mathrm{NaHCO}_{3}+\mathrm{NaCl}+\left(\mathrm{CaCO}_{3}\right)$ in the Badanjilin Desert (figure $2 \mathrm{~g}$ ) and $\mathrm{NaCl}+$ $\mathrm{NaHCO}_{3}$ in the Taklamakan Desert (figure 2h). It indicates that sodium carbonate and chloride are the common salts in aeolian sediments within both the deserts.

The salinities of bulk samples from dune surface in the Taklamakan Desert show a strong positive correlation with the median particle diameters of the corresponding samples ( $\mathrm{Mz}$ in phi unit, figure 3c), indicating an enrichment of soluble salts towards the finer particles of aeolian sediments. A similar trend is also observed in the Badanjilin Desert, as the salt concentrations in different grain size fractions increase as the particle fractions become finer (figure 3d).

The salinities in dune surface sediments from these deserts along the lines of longitude (E) and latitude $(\mathrm{N})$ degrees of sampling sites show regularly varied trends, with an increasing salinity together with the decreases of the longitude and latitude degrees, respectively (figure $3 \mathrm{e}-\mathrm{h}$ ). For the Arerjilin-I section in the Badanjilin Desert, black carbon from the highest shorelines of Arerjilin Lake $(+10 \mathrm{~m})$ were dated to $5628 \pm 221$ calyr BP (CNR185, Supplementary figure $2 \mathrm{a}$ and table S3, Yang et al. 2010). Calcareous gyttja (+6 m) and black carbon $(+5.5 \mathrm{~m})$ from deposits above the lake surface was dated to $4757 \pm 315$ calyr BP (CNR-173) and $7144 \pm 200$ calyr BP (CNR-186, Yang et al. 2010), respectively (Supplementary figure S2a and table S3). Normally, deposits are younger at locations below the highest lake level. However, in this case it is believed that younger sediments were removed by wind erosion. Consequently, the older lacustrine sediments are now exposed to the surface.

The Tazhong-XIII section is a profile containing three layers of the lacustrine deposits intercalated by dune sand sediments (Supplementary figure S2b). The three lacustrine units have similar lithologies and are characterized by horizontal bedding, 
(a)

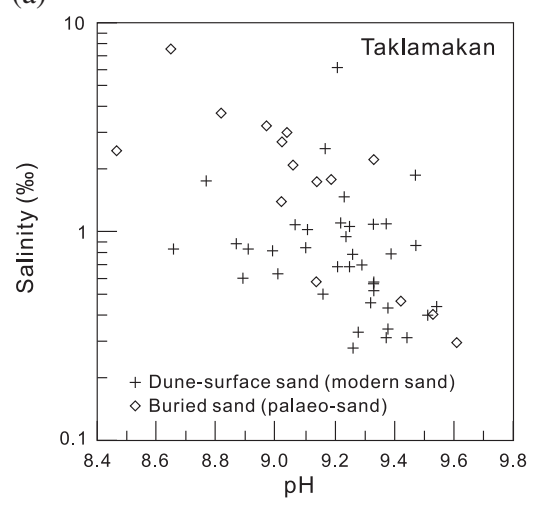

(b)

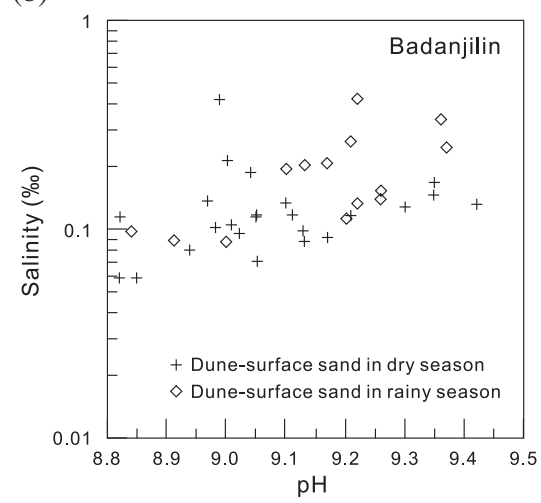

(e)
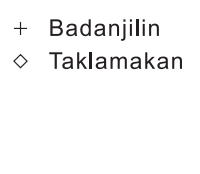

(d)

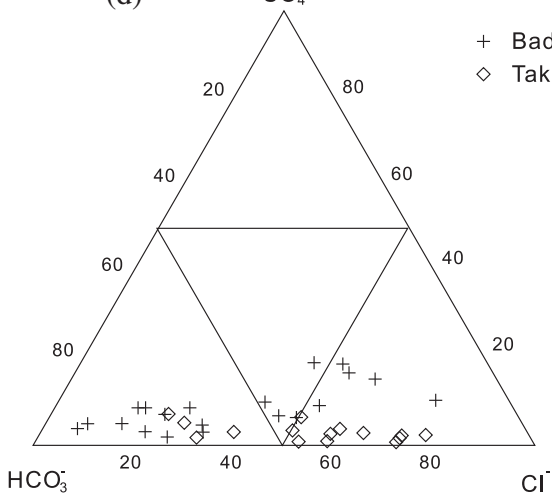

(c)

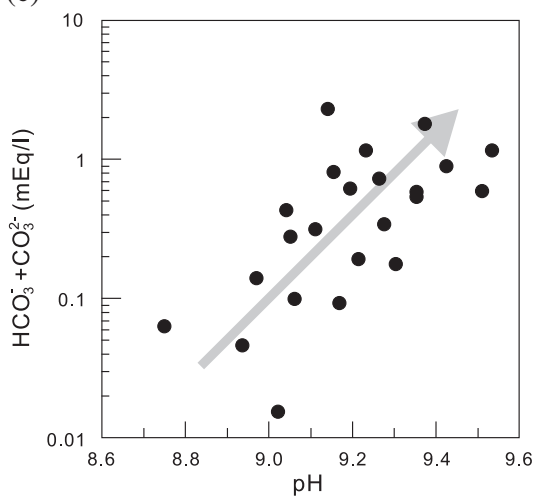

(f)

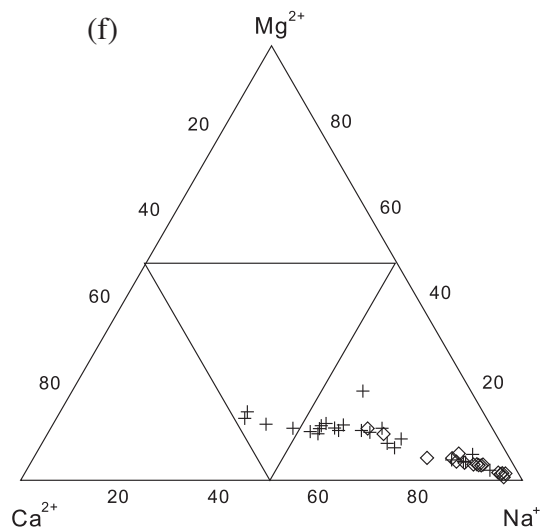

(g)

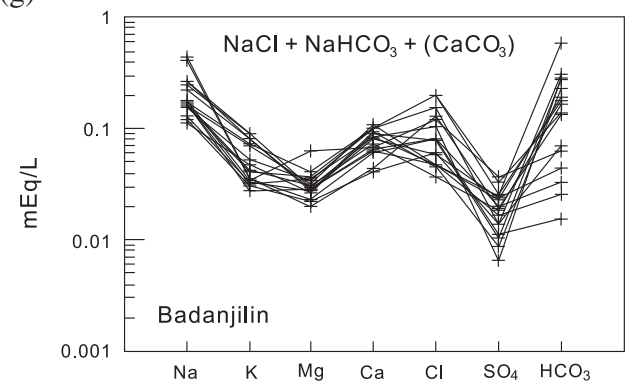

(h)

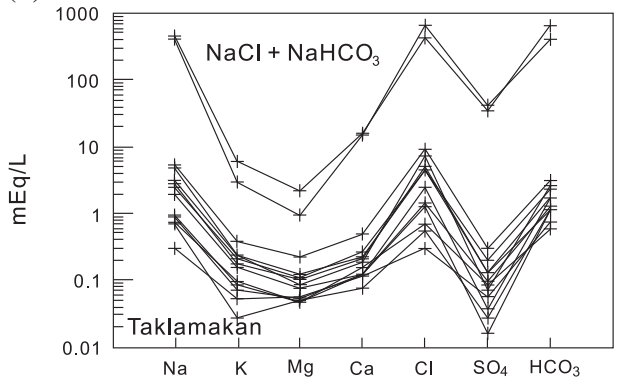

Figure 2. Salinities vs. pH of sediment solutions, (a) dune-surface sediments (modern sediment) and buried-dune sediments (palaeo-sediment) in the Taklamakan Desert, (b) dune-surface sand samples collected in different climatic seasons (dry and wet) in the Badanjilin Desert. (c) Carbon-bearing ions vs. pH. (d) Triangular plots of major anions and (e and f) cations of the soluble salts in $\mathrm{mEq} / \mathrm{l}$ unit. Distribution patterns of the major ions of the soluble salts in the aeolian sediments (g) the Badanjilin Desert and (h) the Taklamakan Desert.

strongly cemented, white in color and have a mean particle size range of 5.8-6.7 phi. The aeolian sediments are unconsolidated and are typically light yellow to dull yellow with a mean particle size of 3.3-3.5 phi, much coarser than the lacustrine deposits. The bottom aeolian layer yields an OSL age of $39,800 \pm 2900$ a (Supplementary table S4, sample TAK 1-1, Yang et al. 2006). Aeolian layers underlying the top two lacustrine layers are dated to $28,000 \pm 2300$ a (TAK 1-2) and $29,200 \pm 2600$ a (TAK 1-3, Yang et al. 2006). The age limits of the lower lacustrine layer are given by the under- and overlying aeolian sand layers and thus are between ca 40,000 and 30,000 a ago. The middle lacustrine layer developed just after 30,000 a in age and the upper layer is younger than this (Supplementary figure $2 \mathrm{~b}$ ).

Lacustrine deposits about $2 \mathrm{~m}$ thick in the Yaogan-VIII section are intercalated with two aeolian sand layers (Supplementary figure S2c). The aeolian sand layers are 8 and $30 \mathrm{~cm}$ thick, for the upper and lower layers, respectively. The aeolian sediments are quite similar to the modern dune sands, yellowish and relatively coarse, with a mean grain size of 3.8 phi. The lacustrine sediments are characterized by horizontal bedding and are 

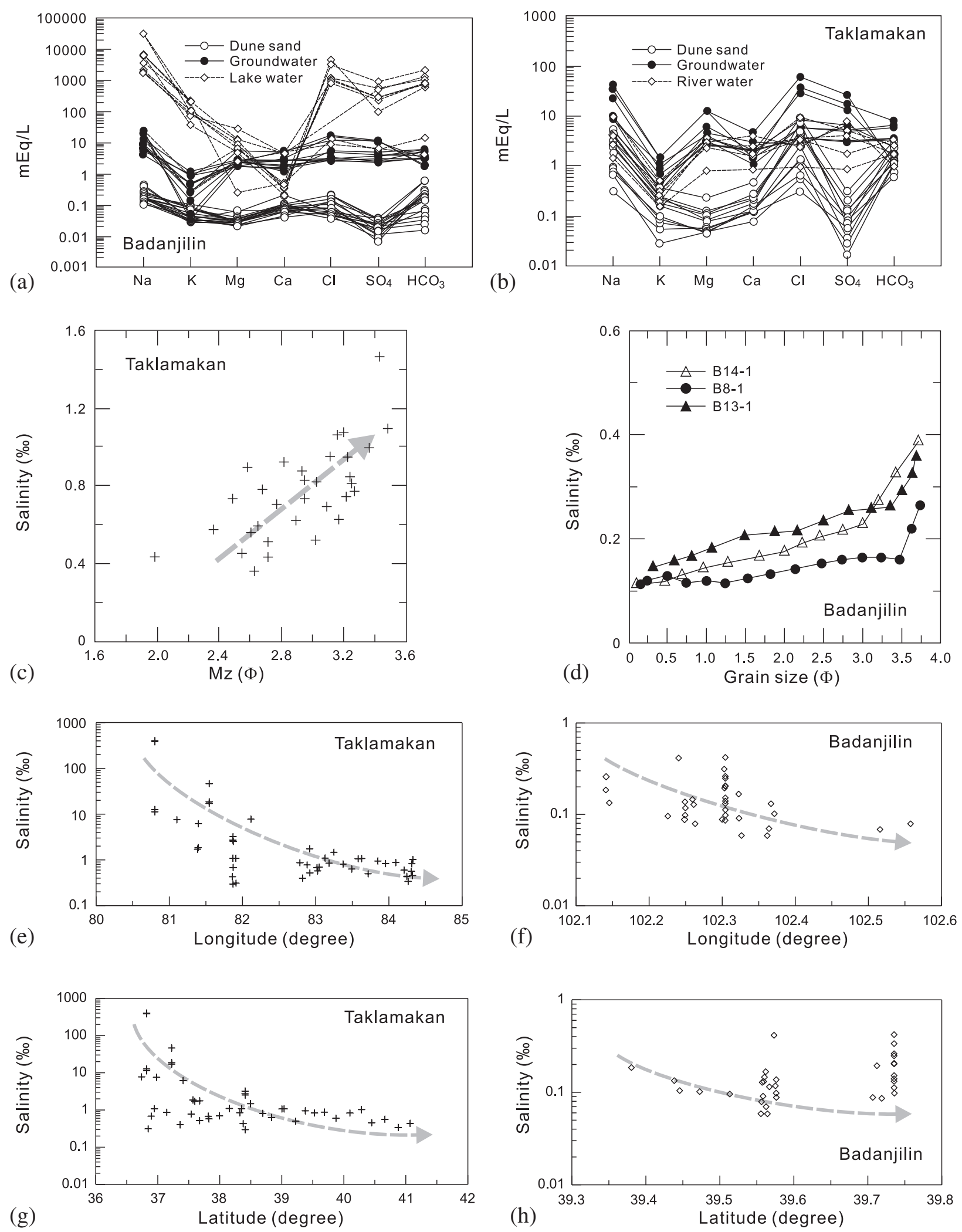

Figure 3. Distribution patterns of the major ions of aeolian salts, groundwaters and lake waters in (a) the Badanjilin Desert and (b) the Taklamakan Desert. The data of local lake water and groundwater bodies in the Badanjilin are cited from Yang and Williams (2003), and the river water and groundwater bodies in the Taklamakan from Zhu and Yang (2007). The relationship between salinities and grain size compositions of the aeolian sediments: (c) salinity vs. median particle diameter (Mz, in phi unit) of dune-surface sediment from the Taklamakan Desert, and (d) salinity vs. grain size compositions of randomly-selected dune sediments from the Badanjilin Desert. Spatial distributions of the salinities of the aeolian sediments along the longitudinal and latitudinal degrees in the Taklamakan Desert (e and $\mathbf{g})$ and in the Badanjilin Desert (f and $\mathbf{h})$, respectively. 
light white in color. The mean particle sizes of the lacustrine deposits in this section are in the range of 4.6-6.2 phi. The aeolian sands underlying the lacustrine section is dated to $14,500 \pm 1100$ a (Supplementary table S4, TAK 6-1, Yang et al. 2006), and the aeolian sands overlying the lacustrine section is dated to $2320 \pm 180$ a (TAK 6-2, Yang et al. 2006). The two intercalated aeolian sand layers suggest that the paleolake was desiccated twice between ca 14,000 and 2000 a (Supplementary figure S2c).

Aeolian silt or sandy loess has been deposited on the palaeoterrace of the Tumiya River near the south margin of the Taklamakan Desert. In the Tumiya-II section, $10 \mathrm{~m}$ of thick sandy silt/loess overlies fluvial gravels (Supplementary figure S2d). Two samples from this section are dated to $23,700 \pm 1800$ a (table S4, TAK 8-1) and $8700 \pm 800 \mathrm{a}$ (TAK 8-2, Yang et al. 2006). The accumulation of sandy loess at this section indicates that southern margin of the Taklamakan Desert at the time between $23,700 \pm 1800$ and $8700 \pm 800$ a was probably not as arid as it is today, because the environment for sandy loess deposition is generally less arid than the environment which produces sand seas.

\section{Discussion}

\subsection{Hydrological implications of aeolian salt composition and distribution}

Basically, all soluble salts are ionic in composition (Marion et al. 1990; Singer 2007). They are originally precipitated from a saturated brine by hydrologies (Warren 2006). It means that the mineralogy and order of precipitates in any brine pool is controlled by the ionic make-up of the parent brine. This provides a clue to reveal the possible sources of aeolian salts.

As previously reported, many arid to semi-arid desert salts are sulphate-rich in areas surrounding the perennial saline lakes, the brine pan depressions and their dune margins (Petrov 1976; Smoot and Lowenstein 1991; Warren 2006; Zhu and Yang 2010; Zhu et al. 2011, 2012; Zhu 2016). For example, gypsum crusts have been reported from all the continents, including Antarctic (El-Sayed 1993). The Kalahari Desert is dominated by chloride-sulfate salts (Wang et al. 2009). Even the wide-distributed aeolian loess deposits in the Loess Plateau of northern China are mainly composed of sulphate salts (Zhu et al. 2011, 2012), such as $\mathrm{Na}_{2} \mathrm{SO}_{4}+\mathrm{NaHCO}_{3}$ in loess and $\mathrm{Na}_{2} \mathrm{SO}_{4}+$ $\mathrm{NaCl}+\mathrm{NaHCO}_{3}$ in paleosol (Sun et al. 2006). This suggests that sulphate $\left(\mathrm{Na}_{2} \mathrm{SO}_{4}\right)$ is one of the major salts in aeolian loess sequences and in low-latitude deserts, but is absent or occurs less commonly in the Chinese deserts in this study.
It indicates that different hydrological effects are responsible for salt formation in aeolian sediments.

In the fingerprint diagram of ion chemistry, the distribution patterns of salt chemistry in aeolian sediments from the Badanjilin Desert are not similar to those of the local groundwater (Zhu and Yang 2010), although both the curves showing the salt concentrations of the aeolian sediments and ground waters are relatively flat in shape (figure 5a). They are also different from those of the region's lake waters (figure 5b). Because most of the dunes in the Badanjilin are higher than $200 \mathrm{~m}$, it is impossible for groundwater to draw upward to the dune surface by capillarity. The chemical differences between aeolian salts and natural water bodies in the Taklamakan Desert are also evident, particularly in the patterns of magnesium and sulfate. These chemical differences between aeolian salts and natural waters from the same place reflect a weaker link between hydrology and aeolian salts at a local scale.

However, the salinities of desert sediments in this study vary along the lines of longitude (E) and latitude $(\mathrm{N})$ degrees of sampling sites at a large scale (figure $5 \mathrm{e}-\mathrm{h}$ ). Because the mean annual precipitation in northern China increases gradually along the same meridional direction, and the temperature or mean solar radiation decreases along the same latitudinal gradients (Zhu and Yang 2010), this indicates that enrichment of aeolian salt has a clear relationship with the changing meridional and zonal gradients of the sample locations, which correspond to the regional climatic conditions characterized by low precipitation and high temperature, as well as the aeolian effects of granularity differentiation caused by wind/atmospheric dynamics.

Wrapping this all together, three characteristics of aeolian salt emerge: first, the wide similarities and partial differences in composition and distribution pattern of the aeolian salt chemistry (figure $4 \mathrm{~g}-\mathrm{h}$ ); second, the weak correlation to the local hydrological settings (figure $5 \mathrm{a}-\mathrm{b}$ ), and third, the strong association with the regional climate and wind regime as indicated by their variation with latitude, longitude and grain size (figure $5 \mathrm{c}-\mathrm{h}$ ). These features indicate that the natural system of aeolian salts in Chinese deserts is hydrologically open and the chemistry of the parent brines and the associated salt deposits may be significantly different than that predicted for hydrologically closed systems. It suggests that the formation of aeolian salts in the deserts is strongly controlled by earthsurface processes in a large scale but not a local scale.

\subsection{Palaeohydrological indications of aeolian salt as an environmental geoproxy}

Desert landscape and bedded salt-bearing lacustrine/fluvial deposits are often part of a long-term 

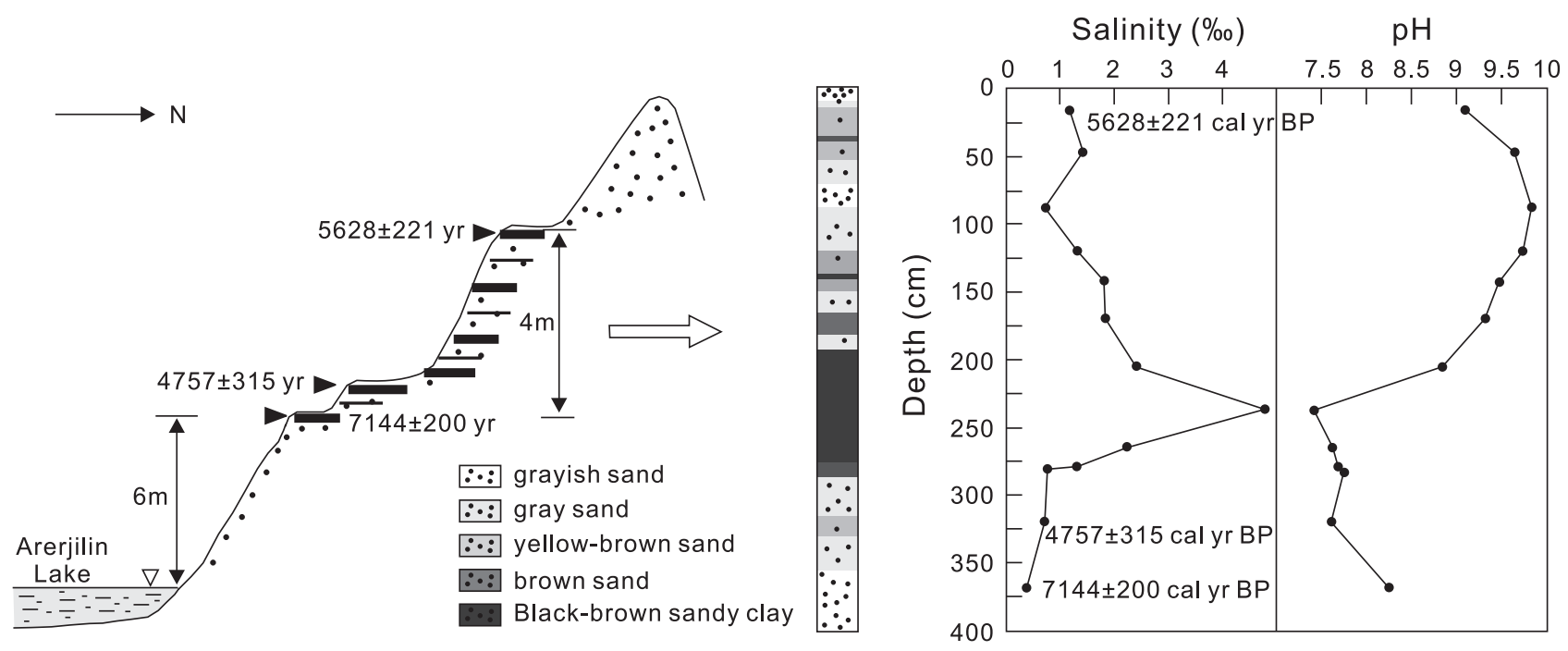

Figure 4. Sequential variations in soluble salt contents (salinity and pH) of the Arerjilin-I section in the Badanjilin Desert.
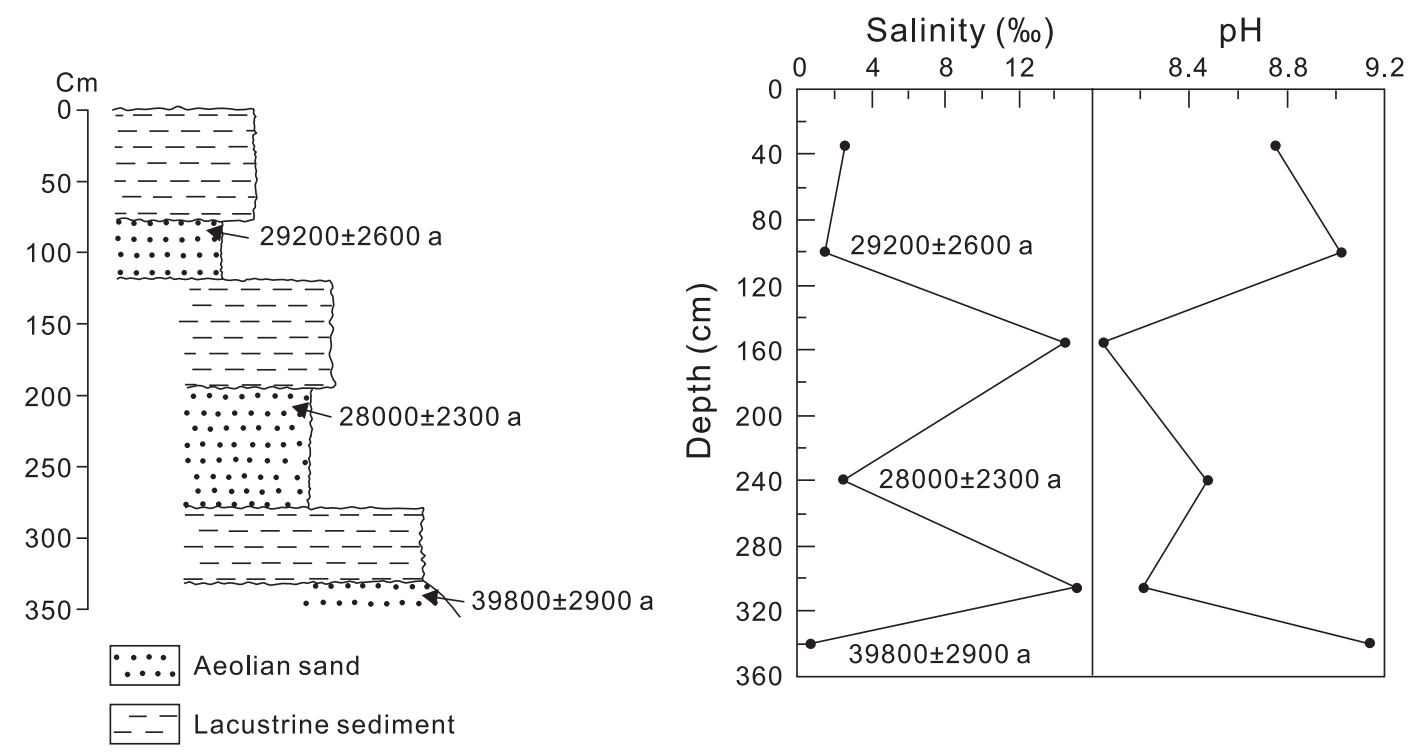

Figure 5. Sequential variations in soluble salt contents (salinity and $\mathrm{pH}$ ) of the Tazhong-XIII section in the Taklamakan Desert.

geological association between sedimentation, hydrology and climate in both extensional and compressional settings and are environmental responses independent of whether the earth is in greenhouse or icehouse climate mode (Hay 1996). Over millions of years in northwestern China, the development of the Qinghai-Tibetan Plateau involves broad upwarping, followed by subsidence of marginal basins, deposition of thick detrital sediments and produce of central adiabatic deserts, which is an evolving climate-hydrology-sediment association that is repeated many times in the Cenozoic.

Large number of playa deposits in these deserts offers an exceptional opportunity to explore the related regional paleohydrological change. OSL and ${ }^{14} \mathrm{C}$ chronologies of aeolian and playa sediments provide an initial framework for understanding the timing of lacustrine/fluvial and aeolian processes associated with hydrological changes. However, despite this increased interest, paleo-limnological and palaeoaeolian research is limited by a paucity of potential geoproxy and study sites with relatively long, uninterrupted stratigraphic sequences in the desert settings.

Besides, is the present the key to the past in salt studies? It is a question that has plagued geologists working with salts since the 17th century, when Werner's neptunist postulates explained world geology as layered precipitates from cooling oceanic waters (Warren 1982, 2006). This paper is not questioning the fundamental principle of using present processes to interpret the past, nor is it questioning 
the utility of detailed studies of modern processes to reliably interpret the past. What the paper is questioning is the strict actualistic approaches to hydrological interpretation of salt geoproxy, whether the depositional diversity is sufficiently broad to explain the diversity of ancient saltbearing sediments in dry land.

Sequential variations of inorganic salts in sediments have been tentatively applied to explore the palaeo-environmental history in world deserts. For example, the Sr-isotopic composition of preserved gypsum in Lake Frome, a large discharge playa in South Australia, is thought to be records of high rainfall periods at $3-6,12-15$, and $>17 \mathrm{ka}$, and of drier periods at about 10 and 17 ka (Ullman and Collerson 1994). In the last interglacial, a nearby and much enlarged lake Eyre had maintained a perennial freshened water body up to $25 \mathrm{~m}$ deep (Magee et al. 1995). In Death Valley, USA, dry mudflats characterized by abundant glauberite, gypsum and minor calcite were thought to be deposited from 0-10 ka and 60-100 ka (Li et al. 1997). In contrast, the wet period from 10-60 ka was typified by halite and mud layers, with relatively abundant calcite. This change is considered to be matching a predominately $\mathrm{Na}-\mathrm{Ca}$ spring-fed inflow during dry climate periods and increased volumes of bicarbonate-rich river waters in the wetter periods ( $\mathrm{Li}$ et al. 1997). Taking the soluble salt concentration variations in thick Cenozoic deposits as one of the indicators of paleo-environmental change, Sun et al. (2008) reconstructed the aridity history of the Tarim Basin, northwestern China and argued that hyper-arid climate had been prevailed within the basin since $5.3 \mathrm{Ma}$ ago.

In this study, the variations in soluble salt contents (e.g., salinity and $\mathrm{pH}$ ) for the four playa sedimentary sequences collected from the Taklamakan and the Badanjilin deserts are examined, as shown in figures $4-7$. The OSL and ${ }^{14} \mathrm{C}$ age constraints of these sequences are also shown in the figures. Vertical changes in facies and salinities are abrupt in these ancient playa systems, a reflection of rapid high amplitude changes in water levels. The salt and chronology data indicates that all of these playa deposits had experienced fluctuations in high moisture conditions during the period from late Pleistocene to mid-Holocene.

Salinity and $\mathrm{pH}$ values of the Arerjilin-I sequence show an increase-decline variation in salinity, and a decline-increase-decline variation in $\mathrm{pH}$, during the early-middle Holocene (figure 4). The salinity curve of the Tazhong-XIII section shows a clear serrate shape (figure 5), suggesting at least three humid periods in the Tazhong area during the past 40 to $28 \mathrm{ka} \mathrm{BP}$. The high salinity values in the Yaogan-VIII section (figure 6) reflect the sediments being saline lacustrine deposits and the regional hydrology having retained these saline conditions for a long duration at the end of the last glacial to late Holocene. The salinity curve of the TumiyaII section shows an unstable character during the LGM (24 ka BP) and two stages of salinity increase during the end of the LGM (about 10-11 ka) and early Holocene (after 8.7 ka BP) (figure 7). Seen from the four sedimentary sequences, the differences in salt content between the aeolian deposits and lacustrine deposits are clear. The salinities of the lacustrine sediments are generally higher than those of aeolian sediments. This indicates a great difference in salt content between different depositional environments, probably due to a difference in mechanism for salt formation and origin. The results suggest that the inorganic salt is a latent proxy for single depositional-environment sequence in revealing local hydrological variations
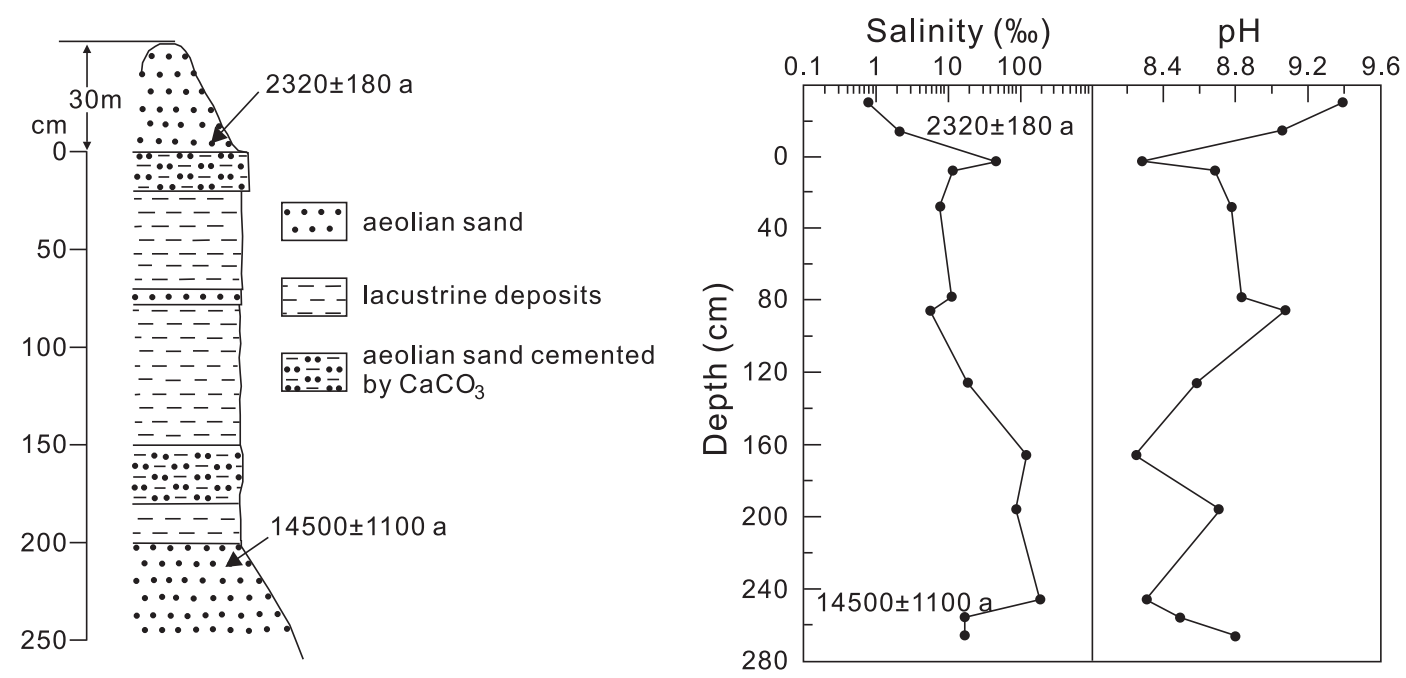

Figure 6. Sequential variations in soluble salt contents (salinity and pH) of the Yaogan-VIII section in the Taklamakan Desert. 

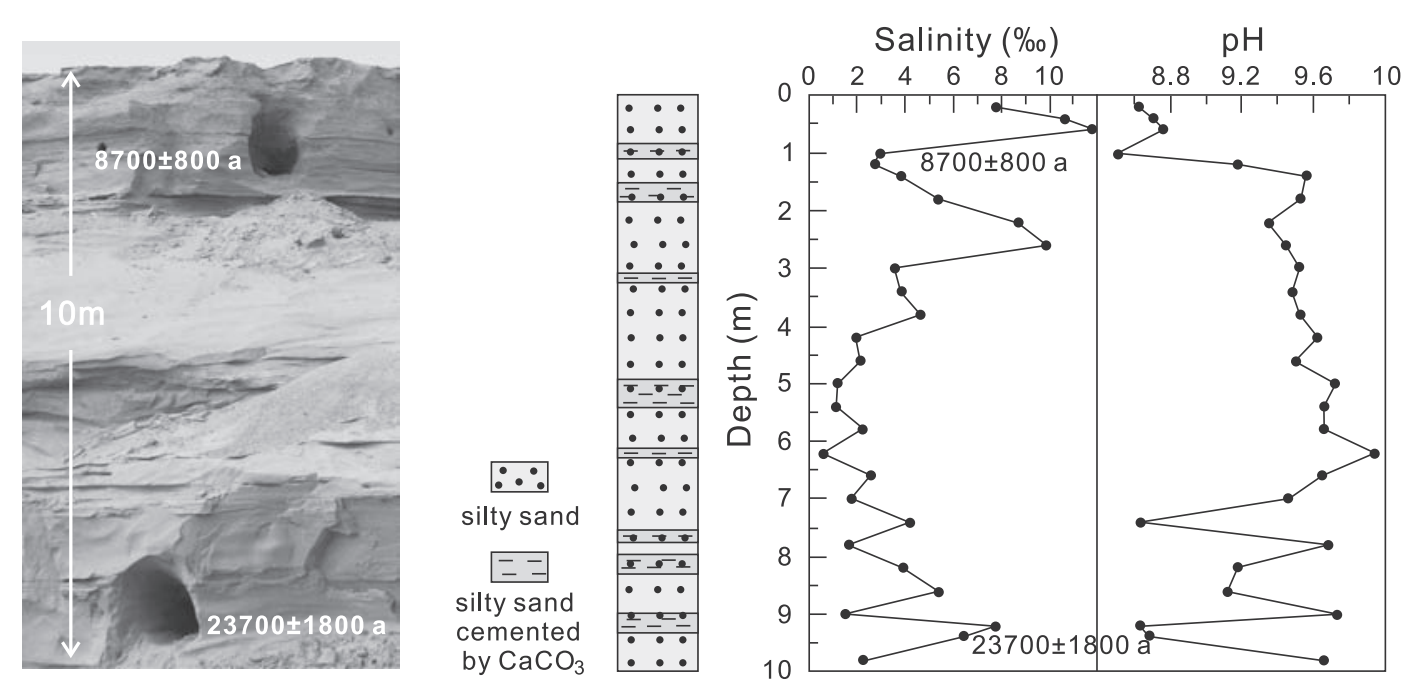

Figure 7. Sequential variations in soluble salt contents (salinity and $\mathrm{pH}$ ) of the Tumiya-II section in the Taklamakan Desert.

and climate change in desert areas during the late Quaternary.

However, the salt indications could be amphibolous for the sedimentary sequences with coexistence of aeolian and lacustrine sediment layers, namely with dual/multiple depositional end-members. For a sedimentary sequence dominated by a uniform geological process (such as lacustrine process or aeolian process), it has been proven that an increase in sequence salinity usually represents an enhanced environmental aridity (Sinha and Raymahashay 2004; Liu et al. 2008). This is because increases in salt content, under both processes, reflect an increased evaporation potential. While in a multi-processes dominated sedimentary sequence, such as a profile intercalated by lacustrine sediments and aeolian sands, an increase in soluble salt content may not indicate an enhanced aridity. This is because the salinities of lacustrine sediments are generally higher than those of aeolian sediments (Zhu and Yang 2010; Zhu et al. 2012). For instance, all the positive excursions in the salt curves for the Arerjilin-I, Tazhong-XIII and Yaogan-VIII sections (figures 4-6) reflect the wetter conditions, because the higher values for salinity generally occurred in the lacustrine strata. The lacustrine layer always represents a wetter period than the aeolian layer under the dunebuilding period (Yang et al. 2006). These sections are not the same as that in the Tumiya-II section (figure 7), because in the latter case the higher values in the salt curve can be reasonably attributed to more arid conditions, due to its single aeolian sedimentation. This means that when aeolian sediments and lacustrine sediments coexist in a sequence under the desert environment, one should be careful to use the salt content alone to reconstruct the local palaeo-environmental history.
Under these contexts, a combination of salt and sedimentary proxy is necessary, as sedimentary proxy such as grain size compositions and distribution patterns are distinguishable between aeolian and lacustrine/fluvial sediments under different depositional dynamics (Xiao et al. 2012; Zhu and $\mathrm{Yu}$ 2014; Zhu et al. 2014).

On the other hand, land surface processes such as chemical, physical and mechanical processes can weld younger to older sediment profiles and affect the accumulation, dissolution, and reprecipitation of mineral materials in sediments, as illustrated by Olson and Nettleton (1998). Sediment properties most affected include texture and the content and distribution of soluble salts. Processes such as erosion and deposition can truncate profiles or bury them either rapidly or extremely slowly. Effects of these and other processes on sediment properties will bias the environmental implications of sediment salinity as a geoproxy. These effects thus should be examined with care in the mix of aeolian and lacustrine sediments that have been buried even for short interval.

Besides the amphibolous indication of vertical changes in salinity in multiple depositional conditions, many sedimentologists will intuitively assume that climate is the major control on water level and salinity in a playa basin. That is, larger deeper playas with thick lacustrine sediment packages should accumulate in wet or humid climatic periods, while drier saline periods should be characterized by saline deposits with lesser aerial extents. But the hydrology of all playa basins, including endorheic basins, is never truly closed and varying degrees of reflux and leakage play significant roles in the final salt deposits (Warren 1982, 2006). For example, concurrent saline lakes and playas in the Badanjilin Deserts can range from hyper-saline to brackish in 
locations only a few kilometers apart (Yang and Williams 2003). So assuming all ancient lakes in an area are arid or humid at the same time based on several sporadic records is not a valid approach to correlation of salt deposits in adjacent saline playa basin in the studied areas.

In summary, the above-mentioned analogies of lacustrine-aeolian profiles in the Taklamakan and Badanjilin deserts should be evaluated carefully in future studies and possibly avoid as single indicators in palaeohydrological reconstruction in the desert environment.

\section{Conclusion}

Formations of inorganic salt in aeolian sediments in the desert environment are critical in understanding the interactions between aoelian processes and regional hydrological and arid-climate systems. Detailed information about the inorganic salt composition and distribution and their hydrological significance in aeolian sediments in the mid-latitude deserts are still rare. Large sandy deserts in northwestern China were investigated for inorganic salt variations in modern and ancient aeolian sediments, aiming to explore their hydrological indications at the present and past. Although sulphate is rich in soils from arid to semi-arid deserts in the world, including the aeolian loess sediments in China and soils in low-latitude deserts, it is less common in the aeolian sediments from the midlatitude deserts in this study. The compositional differences between aeolian salts and local natural waters is evident, indicating the chemistry of the parent brines and the associated aeolian salts may be significantly different than that predicted for hydrologically closed systems. The formation of aeolian salts in the studied deserts is strongly controlled by earth surface processes in a large scale but not in a local scale. Vertical changes in facies and salinities are abrupt in the studied palaeoaeolian sediment samples, which were interbedded by lacustrine/fluvial sediments with OSL and ${ }^{14} \mathrm{C}$ ages ranging between 40 and 2 ka $\mathrm{BP}$, reflecting rapid high-amplitude changes in hydrological settings during late Pleistocene to later Holocene in these ancient playa systems. Great difference in salt composition exists between aeolian and lacustrine sediments, suggesting that the inorganic salt is a latent geoproxy in revealing local hydrological variations and climate change in the desert areas. But the environmental indications could be amphibolous for the sedimentary sequences with multiple depositional end-members, under this situation an increase in sequence salinity does not always represent an enhanced environmental aridity. On the other hand, ancient playas are arid or humid, at the same time based on several sporadic records is not a valid approach to correlation of salt deposits in adjacent saline playa basin. Effects of earth surface processes including erosion, deposition and other processes on sediment properties will bias the hydrological implications of sediment salinity as a geoproxy. These effects should be examined with care in the mix of aeolian and lacustrine sediments that have been buried even for short interval.

\section{Acknowledgements}

This work was financially supported by the National Natural Science Foundation of China (Grant no.: 41371060, 41225001, 41271049) and the Kezhen Young Talent Project of the IGSNRR-CAS (Grant no.: 2013RC101). Sincere thanks are extended to Prof. Xiaoping Yang for his generous help in the field work. The author is also grateful to Rajesh Kumar Srivastava, the Associate Editor of the Journal of Earth System Science, and two anonymous reviewers for their constructive comments, which improved the quality of the manuscript.

\section{References}

Borchert H and Muir R O 1964 Salt deposits: The origin, metamorphism and deformation of evaporites; Van Nostrand Company, London.

Carlson C A, Phillips F M, Elmore D and Bentley H W 1990 Chlorine-36 tracing of salinity sources in the Dry Valleys of Victoria Land, Antarctica; Geochim. Cosmochim. Acta 54 311-318.

Dean W E and Schwalb A 2000 Holocene environmental and climatic change in the Northern Great Plains as recorded in the geochemistry of sediments in Pickerel Lake, South Dakota; Quat. Int. 67 5-20.

El-Sayed M I 1993 Gypcrete of Kuwait field investigation, petrography and genesis; J. Arid Environ. 25 199-203.

Hay W W 1996 Tectonics and climate; Geologische Rundschau 85 409-437.

Hay W W, Migdisov A, Balukhovsky A N, Wold C N, Flogel $\mathrm{S}$ and Soding E 2006 Evaporites and the salinity of the ocean during the phanerozoic implications for climate, ocean circulation and life; Palaeogeogr. Palaeoclimatol. Palaeoecol. 240 3-46.

Last W M 1990 Paleochemistry and paleohydrology of Ceylon Lake, a salt-dominated playa basin in the Northern Great Plains, Canada; J. Paleolimnol. 4 219-238.

Last W M and Vance R E 2002 The Holocene history of Oro Lake, one of the western Canada's longest continuous lacustrine records; Sedim. Geol. 148 161-184.

Li J R, Lowenstein $\mathrm{T} \mathrm{K}$, Brown $\mathrm{C} \mathrm{B}, \mathrm{Ku} \mathrm{T} \mathrm{L}$ and Luo S D 1996 A 100 ka record of water tables and paleoclimates from cores, Death Valley, California; Palaeogeogr. Palaeoclimatol. Palaeoecol. 123 179-203.

Li J R, Lowenstein T K and Blackburn I R 1997 Responses of evaporite mineralogy to inflow water sources and climate during the past $100 \mathrm{ky}$ in Death Valley California; Geol. Soc. Am. Bull. 109 1361-1371.

Liu X, Dong H, Rech J A, Matsumoto R, Yang B and Wang Y 2008 Evolution of Chaka Salt Lake in NW 
China in response to climatic change during the Latest Pleistocene-Holocene; Quat. Sci. Rev. 27 867-879.

Magee J W 1991 Late Quaternary lacustrine, groundwater, aeolian and pedogenic gypsum in the Prungle Lakes, southeastern Australia; Palaeogeogr. Palaeoclimatol. Palaeoecol. 84 229-257.

Magee J W and Miller G H 1998 Lake Eyre palaeohydrology from $60 \mathrm{ka}$ to the present beach ridges and glacial maximum aridity; Palaeogeogr. Palaeoclimatol. Palaeoecol. $144307-329$.

Magee J W, Bowler J M, Miller G H and Williams D L G 1995 Stratigraphy, sedimentology, chronology and palaeohydrology of Quaternary lacustrine deposits at Madigan Gulf, Lake Eyre, South Australia; Palaeogeogr. Palaeoclimatol. Palaeoecol. 113 3-42.

Magee J W, Miller G H, Spooner N A and Questiaux D 2004 Continuous 150 k.y. monsoon record from lake Eyre, Australia insolation-forcing implications and unexpected Holocene failure; Geology 32 885-888.

Marion G M, Schlesinger W H and Fonteyn P J 1990 Spatial variability of $\mathrm{CaCO}_{3}$ solubility in a Chihuahuan desert soil; Arid Soil Res. Rehab. 4 181-191.

Marion G M, Farren R and Komrowski A 1999 Alternative pathways for seawater freezing; Cold Regions Science and Technology 29 259-266.

Marion G M, Verberg P S J, McDonald E V and Arnone J A 2008 Modeling salt movement through a Mojave Desert soil; J. Arid Environ. 72 1012-1033.

Olson C G and Nettleton W D 1998 Paleosols and the effects of alteration; Quat. Int. 51/52 185-194.

Petrov M P 1976 Deserts of the World; John Wiley \& Sons, New York.

Schutt B 2000 Holocene paleohydrology of playa-lake systems in central Spain: A reconstruction based on mineral composition of the lacustrine sediments; Quat. Int. $73 / 747-27$.

Singer A 2007 Introduction on arid zone soil:salt accumulation and distribution - saline soils; In: Biogeochemistry of trace elements in arid environments (ed.) Han F X, Springer, Dordrecht, pp. 3-44.

Sinha R and Raymahashay B C 2004 Evaporite mineralogy and geochemical evolution of the Sambhar Salt Lake, Rajasthan, India; Sedim. Geol. 166 59-71.

Singh B P, Singh N and Singh S P 2013 Modern salt (halite) deposits of the Sambhar lake, Rajasthan and their formative conditions; Curr. Sci. 104(11) 1482-1484.

Smoot J P and Lowenstein T K 1991 Depositional environments of non-marine evaporates; In: Evaporites, Petroleum and Mineral Resources (ed.) Melvin J L, Elsevier, Amsterdam, pp. 189-347.

Sun B, Guo Z, Yin Q and Hao Q 2006 Soluble salts in a Quaternary loess-soil sequence near Xining and their environmental implications; Quat. Sci. 26(4) 649-656 (in Chinese).

Sun J, Zhang L, Deng C and Zhu R 2008 Evidence for enhanced aridity in the Tarim Basin of China since 5.3 Ma; Quat. Sci. Revi. 27 1012-1023.

Ullman W J 1995 The fate and accumulation of bromide during playa salt deposition: An example from Lake Frome, South Australia; Geochim. Cosmochim. Acta 59 2175-2186.
Ullman W J and Collerson K D 1994 The Sr-isotope record of late Quaternary hydrologic changes around Lake Frome, South Australia; Australian J. Earth Sci. 41 37-45.

Wang L, D'Odorico P, Okin G and Macko S 2009 Isotope composition and anion chemistry of soil profiles along the Kalahari Transect; J. Arid Environ. 73 480-486.

Warren J K 1982 Hydrologic setting, occurrence, and significance of gypsum in late Quaternary salt lakes, South Australia; Sedimentology 29 609-637.

Warren J K 2006 Evaporites: Sediments, resources and hydrocarbons; Springer, Berlin.

Wasson R J, Smith G I and Agrawal D P 1984 Late Quaternary sediments, minerals, and inferred geochemical history of Didwana lake, Thar Desert, India; Palaeogeogr. Palaeoclimatol. Palaeoecol. 46 345-372.

Wetzel R G and Likens G E 2000 Limnological analyses, 3rd edn, Springer, New York.

Xiao J, Chang Z, Fan J, Zhou L, Zhai D, Wen R and Qin X 2012 The link between grain-size components and depositional processes in a modern cliastic lake; Sedimentology 59 1050-1062.

Yang X and Williams M A J 2003 The ion chemistry of lakes and late Holocene desiccation in the BadainJaran Desert, Inner Mongolia, China; Catena 51 45-60.

Yang X, Preusser F and Radtke U 2006 Late Quaternary environmental changes in the Taklamakan Desert, western China, inferred from OSL-dated lacustrine and aeolian deposits; Quat. Sci. Rev. 25 923-932.

Yang X, Ma N, Dong J, Zhu B, Xu B, Ma Z and Liu J 2010 Recharge to the inter-dune lakes and Holocene climatic changes in the BadainJaran Desert, western China; Quat. Res. 73 10-19.

Yang X, Scuderi L, Paillou P, Liu Z, Li H and Ren X 2011 Quaternary environmental changes in the drylands of China - A critical review; Quat. Sci. Rev. 30 32193233 .

Zhu B 2016 Atmospheric significance of aeolian salts in the sandy deserts of northwestern China; Solid Earth 7 191203.

Zhu B and Yang X 2007 The ion chemistry of surface and ground waters in the Taklimakan Desert of Tarim Basin, western China; Chinese Sci. Bull. 52 2123-2129.

Zhu B and Yang X 2010 The origin and distribution of soluble salts in the sand seas of northern China; Geomorphology 123 232-242.

Zhu B and Yu J 2014 Aeolian sorting processes in the Ejina desert basin (China) and their response to depositional environment; Aeolian Res. 12 111-120.

Zhu B, Yang X, Rioual P, Liu Z, Li C and Xiong H 2011 Composition of soluble salts in aeolian sands from sandy deserts of Northern China and their environmental implications; Quat. Sci. 31 1029-1044 (in Chinese).

Zhu B, Yang X, Liu Z, Rioual P, Li C and Xiong H 2012 Geochemical compositions of soluble salts in aeolian sands from the Taklamakan and Badanjilin deserts in northern China, and their influencing factors and environmental implications; Environ. Earth Sci. 66 337-353.

Zhu B Q, Yu J J, Rioual P and Ren X Z 2014 Particle size variation of aeolian dune deposits in the lower reaches of the Heihe River basin, China; Sedim Geol. 301 54-69. 